\title{
Genetic characterization of eastern Atlantic hawksbill turtles at a foraging group indicates major undiscovered nesting populations in the region
}

\author{
Catalina Monzón-Argüello ${ }^{\text {a,b,c, }} \square$, Ciro Rico ${ }^{b}$, Adolfo Marco ${ }^{\text {b }}$, Pedro López ${ }^{\text {d }}$, Luis Felipe López-Jurado ${ }^{c}$ \\ a Instituto Canario de Ciencias Marinas, Crta. de Taliarte s/n, 35200 Telde, Gran Canaria, Spain \\ ${ }^{\mathrm{b}}$ Estación Biológica de Doñana (CSIC), Américo Vespucio, s/n, 41092 Sevilla, Spain \\ c Dpto. de Biología, Universidad de Las Palmas de G.C. Campus de Tafira, 35017 Las Palmas de Gran Canaria, Gran Canaria, Spain \\ ${ }^{\mathrm{d}}$ Naturalia, Cape Verde Ltd. Sal-Rei. Boa Vista, Republic of Cape Verde
}

\section{Keywords:}

Eretmochelys imbricata

Eastern Atlantic

Conservation genetics

Mitochondrial DNA

Foraging grounds

Connectivity

\begin{abstract}
a b s t r a c t
Despite the considerable population genetic and connectivity research on the hawksbill sea turtle (Eretmochelys imbricata) and the species being critically endangered, the eastern Atlantic remains understudied. We present the first analysis of mitochondrial DNA (mtDNA) sequences $(n=28)$ of hawksbill juveniles in a foraging aggregation at the Cape Verde Islands. Our results showed three haplotypes nonreported in any nesting population to date, with one of them accounting for $68 \%$ of the samples. These three haplotypes were closely related to each other but highly divergent from all known Caribbean and Western Atlantic haplotypes. These findings highlight the necessity of additional research, particularly expanding the genetic analyses throughout the western coast of Africa to include unsampled areas. Furthermore, we found three haplotypes (A, B, and F; 14\% of the total samples) previously detected in rookeries from the western Atlantic. The genetic data presented here carried significant conservation and research applications.
\end{abstract}

\section{Introduction}

The hawksbill sea turtle (Eretmochelys imbricata) is a circumglobal tropical species, with a typically particular diet that includes several species of marine sponges and cnidarians (Meylan, 1988; Márquez, 1990; León and Bjorndal, 2002). Hawksbill turtles have been extensively exploited for centuries for tortoiseshell (Parsons, 1972; Groombridge and Luxmoore, 1989; Meylan, 1999). For example, more than 10,000 Caribbean turtles/year has been harvested in recent decades (Canin, 1989), and many nesting populations are greatly reduced or extinct as a result of this exploitation (Bowen et al., 2007a). Consequently, the species is listed as Critically Endangered by the International Union for the Conservation of Nature and Natural Resources - IUCN (Mortimer and Donnelly, 2008).

After hatchling, hawksbills develop in the oceanic zone for a period, followed by a later stage in the neritic zone. In general, the biology of this species has been less studied than other sea turtles; for example the age of recruitment to neritic habitats remains unknown but it occurs with smaller sizes than those of the loggerheads (Caretta caretta), suggesting that the duration of the oceanic phase in this species may be shorter (Bolten, 2003). Although some stocks of hawksbill sea turtles from the Caribbean and western Atlantic Ocean remain under analysis, several

Corresponding author. Instituto Canario de Ciencias Marinas, Crta. de Taliarte s/n, 35200 Telde, Gran Canaria, Spain. Tel.: +34 132900; fax: +34 132908.

E-mail address: catalinama@iccm.rcanaria.es (C. Monzón-Argüello). populations have been identified in these regions: (1) Cuba; (2) Puerto Rico; (3) US Virgin Islands; (4) Antigua; (5) Barbados; (6) Venezuela; (7) Costa Rica; (8) Belize; (9) Mexico; and (10) Brazil (Fig. 1). While it is known that at least one stock occurs around the rookeries of São Tome and Principe and Bioko Islands, the eastern border remain genetically unexplored (Fretey, 2001; Bowen et al., 2007b; Abreu and Le Roux, 2008).

While large juvenile and adult turtles can be accurately tracked for long periods (Schofield et al., 2007), it is currently impossible to directly track hatchlings and small juveniles for extended periods because of the size of tags. Therefore to compliment direct tracking, genetic differences based on mtDNA have been extensively used to identify the origins of migratory juveniles using mixed-stock analysis (MSA). This has been applied to hawksbills to study juvenile aggregations and foraging grounds in Australia (Broderick et al., 1994), and the Caribbean region (Bowen et al., 1996, 2007b; Díaz-Fernández et al., 1999; Troëng et al., 2005; Blumenthal et al., 2009). The composition of juvenile aggregations may be affected by several factors like nesting population size, oceanic currents, and the natal homing behaviour, where juveniles try to recruit to feeding areas near to their natal rookeries (Bowen et al., 2007b; Bowen and Karl, 2007; Velez-Zuazo et al., 2008; Blumenthal et al., 2009). Among these, oceanic currents have been shown to play a substantial role in defining the genetic structure of foraging aggregations (Blumenthal et al., 2009). Furthermore, larger nesting populations may contribute more juveniles to these aggregations (Bowen et al., 2007b). In the eastern Atlantic, low number of hawksbills now nests in 


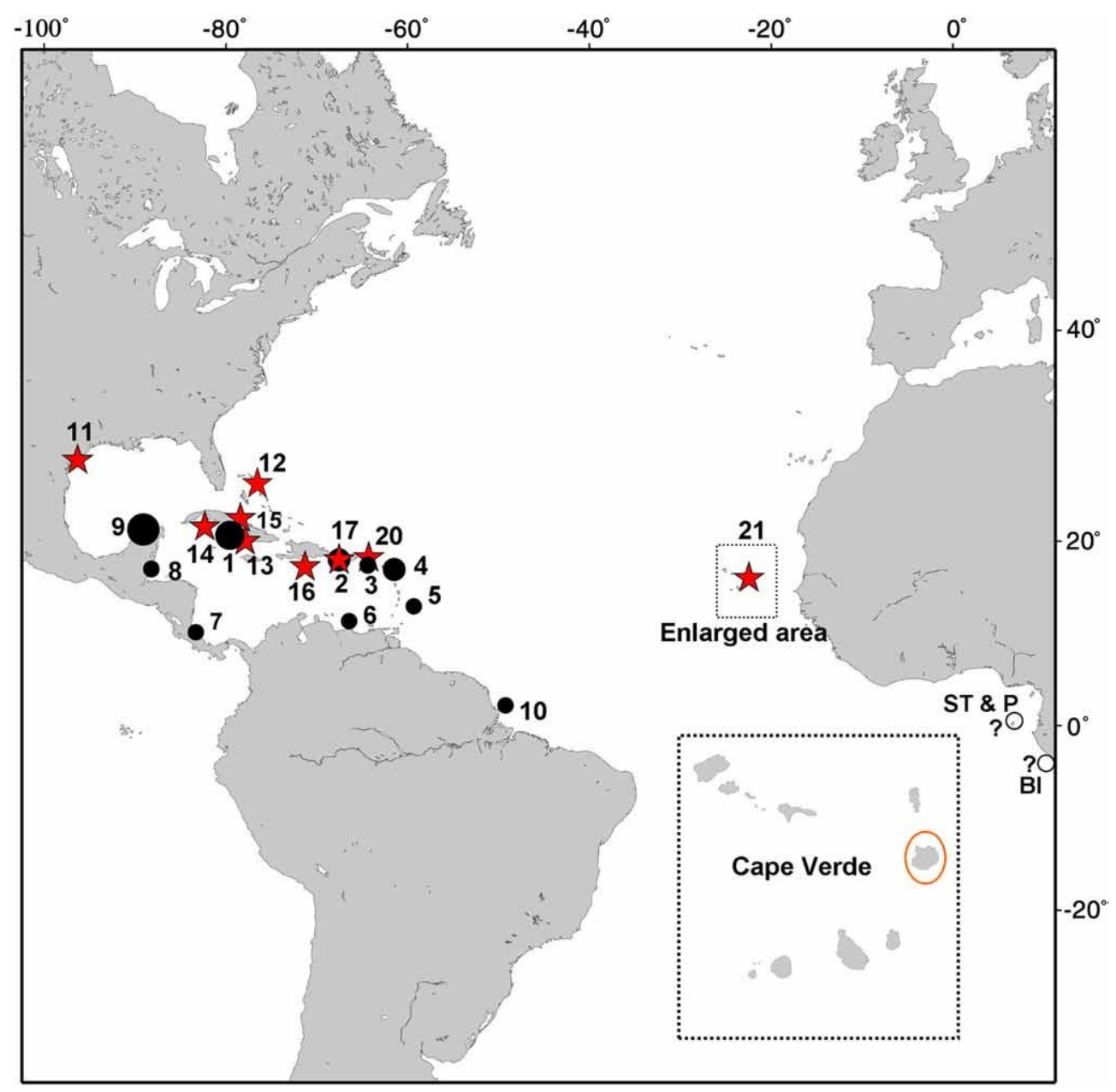

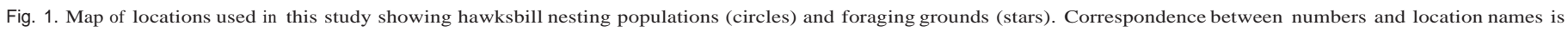

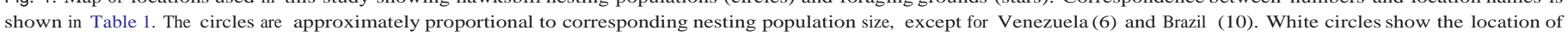
Sao Tome and Principe and Bioko rookeries, genetically undescribed (?). Red circle shows the studied area in Cape Verde.

all west and central Africa each year, with the best nesting on Bioko Island (Equatorial Guinea, b7 females/year; Mortimer and Donnelly 2008) and the islands of Sao Tome and Príncipe (b30 females/year; N. S. Loureiro pers. comm. based on ONG MARAPA data; Mortimer and Donnelly 2008). However, large numbers of nesting activity occur in the western Atlantic (e.g. Barbados with 483 females/season, Mexico with 534-891 females/season; Beggs et al., 2007; Mortimer and Donnelly 2008; Table 1).

In this paper, we analysed mtDNA sequences from a hawksbill foraging aggregation of Cape Verde Islands, an archipelago located about $600 \mathrm{~km}$ west of Senegal where several hundreds of juveniles are found around all the year. The information derived from this analysis is intended to provide initial insights of the hawksbill genetic stocks in the eastern Atlantic and the level of transoceanic movement that may be taking place.

\section{Material and methods}

Daytime free-diving surveys were conducted in coastal areas less than $15 \mathrm{~m}$ deep. The in-water work was carried out by a team of 2-4 divers at Boavista Island (Cape Verde) during 2000, 2001, 2007 and 2008. Juvenile turtles were hand captured and brought aboard to a small boat and/or taken ashore for tagging, sampling and data recording. Each captured turtle was measured (minimum curve carapace length - min CCL, following Bolten, 1999). All turtles greater than $25 \mathrm{~cm}$ CCL were tagged in both front flippers using metal tags. A passive integrated transponder (Avid $\AA$ ) was injected into the right front flipper of all size classes. A skin sample was collected from the tip of the right rear flipper and preserved in a salt-saturated $20 \%$ DMSO or $96 \%$ ethanol solution. Genomic DNA was isolated using the DNeasy Tissue Kit (QIAGEN®). A 760 base pair (bp) fragment of the mtDNA control region was amplified by the polymerase chain reaction (PCR) using the primers LCM15382 and H950 (Abreu-Grobois et al., 2006). Up to $2 \mu \mathrm{l}$ of extracted DNA (60 ng) was used in $20 \mu \mathrm{L}$ PCR mixes containing $0.5 \mu \mathrm{M}$ of each primer, $0.25 \mathrm{mM}$ dNTPs, $0.6 \mathrm{U}$ of Taq DNA polymerase (Bioline), PCR buffer $1 \times$ (Bioline), $0.2 \mu \mathrm{g} / \mu \mathrm{l} \mathrm{BSA}$, and $2 \mathrm{mM} \mathrm{MgCl}_{2}$ (Bioline). The thermal conditions were an initial denaturation step at $94{ }^{\circ} \mathrm{C}$ for $2 \mathrm{~min}$; followed by 40 cycles of $94{ }^{\circ} \mathrm{C}$ for $1 \mathrm{~min}, 55^{\circ} \mathrm{C}$ for $1 \mathrm{~min}, 72^{\circ} \mathrm{C}$ for $1 \mathrm{~min}$; with a final extension at $72{ }^{\circ} \mathrm{C}$ for $5 \mathrm{~min}$. Cycle sequencing reactions were conducted with Big Dye fluorescent dye-terminator (Applied Biosystems) according to manufactures' instructions and the fragments were analyzed on an automated sequencer (Applied Biosystems Inc. model 3100). Chromatograms were checked and aligned using Bioedit Sequence Alignment Editor v.7.0.9 (http://www.mbio.ncsu.edu/BioEdit/bioedit.html). To assure broad comparisons of our results with previous studies, our control region sequence alignment was trimmed to 384 bp of length. Haplotype designation followed that from previous publications (Bass et al., 1996; Bowen et al., 1996, 2007b; DíazFernández et al., 1999; Browne et al., in press). Deletion in haplotype D at position 59 and a 10-bp insertion at position 354 in haplotype MX1A were treated as single substitutions following Bowen et al. (2007b). FindModel (http://www.hiv.lanl.gov) determined the best model of nucleotide substitution that fits the data. Haplotype data was obtained using DnaSP v. 5 (http://www.ub.es/dnasp/) and was used to construct 
Table 1

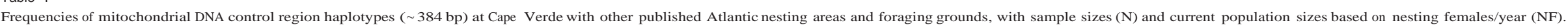

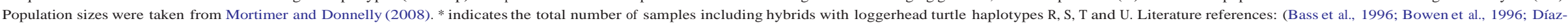
Fernández et al., 1999; Troëng et al., 2005; Bowen et al., 2007b; Browne et al., in press).

\begin{tabular}{|c|c|c|c|c|c|c|c|c|c|c|c|c|c|c|c|c|c|c|c|c|c|c|c|c|c|c|c|c|c|c|c|c|c|c|c|c|}
\hline Location & $\mathrm{N}$ & A & в & C & D & E & $\mathrm{F}$ & G & $\mathrm{H}$ & I & J & $\mathrm{K}$ & L & M & $\mathrm{N}$ & o & $\mathrm{P}$ & $\mathrm{Q}$ & $\mathrm{R}$ & $\mathrm{s}$ & $\mathrm{T}$ & $\mathrm{U}$ & BI1 & $\alpha$ & $\beta$ & $\mathrm{r}$ & $\mathrm{Cu} 3$ & $\mathrm{Cu} 4$ & Cum & DR1 & DR2 & Mx1a & EATL & Ei-A49 & Ei-A82 & $\mathrm{NF}$ \\
\hline \multicolumn{37}{|l|}{ Nesting areas } \\
\hline 1. Cuba & 70 & 62 & 0 & 0 & 0 & 0 & 1 & 0 & 0 & 0 & 0 & 0 & 0 & 0 & 0 & 0 & 0 & 0 & 0 & 0 & 0 & 0 & 0 & 0 & 0 & 5 & 1 & 1 & 0 & 0 & 0 & 0 & 0 & 0 & 0 & $400-833$ \\
\hline 2. Puerto Rico & 35 & 1 & 0 & 0 & 0 & 0 & 13 & 0 & 0 & 0 & 2 & 1 & 2 & 2 & 12 & 2 & 0 & 0 & 0 & 0 & 0 & 0 & 0 & 0 & 0 & 0 & 0 & 0 & 0 & 0 & 0 & 0 & 0 & 0 & 0 & $250-417$ \\
\hline 3. US Virgin Islands & 51 & 5 & 1 & 0 & 0 & 0 & 43 & 0 & 0 & 0 & 0 & 0 & 0 & 0 & 0 & 0 & 0 & 0 & 0 & 0 & 0 & 0 & 1 & 0 & 0 & 0 & 0 & 0 & 0 & 0 & 0 & 0 & 0 & 0 & 0 & $86-278$ \\
\hline 4. Antigua & 15 & 9 & 4 & 2 & 0 & 0 & 0 & 0 & 0 & 0 & 0 & 0 & 0 & 0 & 0 & 0 & 0 & 0 & 0 & 0 & 0 & 0 & 0 & 0 & 0 & 0 & 0 & 0 & 0 & 0 & 0 & 0 & 0 & 0 & 0 & $100-125$ \\
\hline 5. Barbados L. & 54 & 54 & 0 & 0 & 0 & 0 & 0 & 0 & 0 & 0 & 0 & 0 & 0 & 0 & 0 & 0 & 0 & 0 & 0 & 0 & 0 & 0 & 0 & 0 & 0 & 0 & 0 & 0 & 0 & 0 & 0 & 0 & 0 & 0 & 0 & 483 \\
\hline 6. Barbados W. & 30 & 3 & 0 & 0 & 0 & 0 & 27 & 0 & 0 & 0 & 0 & 0 & 0 & 0 & 0 & 0 & 0 & 0 & 0 & 0 & 0 & 0 & 0 & 0 & 0 & 0 & 0 & 0 & 0 & 0 & 0 & 0 & 0 & 0 & 0 & \\
\hline 7. Venezuela & 7 & 7 & 0 & 0 & 0 & & 0 & 0 & 0 & 0 & 0 & 0 & 0 & 0 & 0 & 0 & 0 & 0 & 0 & 0 & 0 & 0 & 0 & 0 & 0 & 0 & 0 & 0 & 0 & 0 & 0 & 0 & 0 & 0 & 0 & $32-53$ \\
\hline 8. Costa Rica & 57 & 0 & 0 & 0 & 0 & 0 & 33 & 6 & 0 & 0 & 0 & 0 & 4 & 0 & 0 & 0 & 0 & 0 & 0 & 0 & 0 & 0 & 0 & 10 & 0 & 0 & 4 & 0 & 0 & 0 & 0 & 0 & 0 & 0 & 0 & 10 \\
\hline 9. Belize & 14 & 0 & 0 & 0 & 0 & 0 & 11 & 1 & 1 & 1 & 0 & 0 & 0 & 0 & 0 & 0 & 0 & 0 & 0 & 0 & 0 & 0 & 0 & 0 & 0 & 0 & 0 & 0 & 0 & 0 & 0 & 0 & 0 & 0 & 0 & $8-56$ \\
\hline 10. Мexico & 69 & 0 & 0 & 0 & 0 & 0 & 0 & 0 & 0 & 0 & 0 & 0 & 0 & 0 & 0 & 0 & 3 & 64 & 0 & 0 & 0 & 0 & 1 & 0 & 0 & 0 & 0 & 0 & 0 & 0 & 0 & 1 & 0 & 0 & 0 & $534-891$ \\
\hline 11. Brazil & $5\left(18^{*}\right)$ & 5 & 0 & 0 & 0 & 0 & 0 & 0 & 0 & 0 & 0 & 0 & 0 & 0 & 0 & 0 & 0 & 0 & 9 & 2 & 1 & 1 & 0 & 0 & 0 & 0 & 0 & 0 & 0 & 0 & 0 & 0 & 0 & 0 & 0 & $350-585$ \\
\hline TOTAL & 347 & 109 & 5 & 2 & 1 & 3 & 101 & 7 & 1 & 1 & 2 & 1 & 6 & 2 & 12 & 2 & 3 & 64 & 9 & 2 & 1 & 1 & 2 & 10 & 0 & 5 & 5 & 1 & 0 & 0 & 0 & 1 & 0 & 0 & 0 & \\
\hline \multicolumn{37}{|l|}{ Foraging grounds } \\
\hline 11. Texas & 42 & 0 & 0 & 0 & 0 & 0 & 3 & 0 & 0 & 0 & 0 & 0 & 0 & 0 & 0 & 0 & 0 & 38 & 0 & 0 & 0 & 0 & 0 & 0 & 0 & 0 & 0 & 0 & 0 & 0 & 0 & 1 & 0 & 0 & 0 & \\
\hline 12. Bahamas & 78 & 28 & 1 & 0 & 0 & 0 & 20 & 0 & 0 & 0 & 0 & 0 & 0 & 0 & 2 & 0 & 1 & 21 & 0 & 0 & 0 & 0 & 0 & 1 & 0 & 0 & 23 & 0 & 0 & 1 & 0 & 0 & 0 & 0 & 0 & \\
\hline 13. Cuba A & 43 & 28 & 0 & 0 & 0 & 0 & 6 & 0 & 0 & 0 & 0 & 0 & 0 & 0 & 0 & 0 & 0 & 3 & 0 & 0 & 0 & 0 & 0 & 2 & 0 & 1 & 2 & 0 & 0 & 1 & 0 & 0 & 0 & 0 & 0 & \\
\hline 14. Cuba B & 111 & 46 & 0 & 0 & 0 & 0 & 34 & 0 & 0 & 0 & 0 & 0 & 1 & 0 & 10 & 0 & 0 & 11 & 0 & 0 & 0 & 0 & 0 & 1 & 0 & 5 & 2 & 0 & 0 & 1 & 0 & 0 & 0 & 0 & 0 & \\
\hline 15. Cuba D & 56 & 18 & 1 & 0 & 0 & 0 & 13 & 1 & 0 & 0 & 0 & 0 & 2 & 0 & 3 & 0 & 0 & 8 & 0 & 0 & 0 & 0 & 0 & 2 & 0 & 5 & 0 & 0 & 1 & 0 & 0 & 0 & 0 & 0 & 0 & \\
\hline 16. Dominican Rep. & 90 & 42 & 0 & 0 & 0 & 0 & 30 & 2 & 0 & 0 & 1 & 0 & 1 & 0 & 0 & 0 & 0 & 6 & 0 & 0 & 0 & 0 & 0 & 6 & 0 & 0 & 0 & 0 & 0 & 1 & 1 & 0 & 0 & 0 & 0 & \\
\hline 17. Puerto Rico pooled & 138 & 38 & 2 & 0 & 0 & 0 & 62 & 0 & 0 & 0 & 0 & 0 & 3 & 0 & 8 & 0 & 0 & 18 & 0 & 0 & 0 & 0 & 0 & 5 & 1 & 1 & 0 & 0 & 0 & 0 & 0 & 0 & 0 & 0 & 0 & \\
\hline 18. Puerto Rico 1993 & 41 & 7 & 1 & 0 & 0 & 0 & 18 & 0 & 0 & 0 & 0 & 0 & 1 & 0 & 3 & 0 & 0 & 7 & 0 & 0 & 0 & 0 & 0 & 2 & 1 & 1 & 0 & 0 & 0 & 0 & 0 & 0 & 0 & 0 & 0 & \\
\hline 19. Puerto Rico 1999 & 97 & 31 & 1 & 0 & 0 & 0 & 44 & 0 & 0 & 0 & 0 & 0 & 2 & 0 & 5 & 0 & 0 & 11 & 0 & 0 & 0 & 0 & 0 & 3 & 0 & 0 & 0 & 0 & 0 & 0 & 0 & 0 & 0 & 0 & 0 & \\
\hline 20. USVI & 68 & 28 & 2 & 0 & 0 & 0 & 17 & 0 & 0 & 0 & 0 & 0 & 0 & 0 & 6 & 0 & 0 & 9 & 0 & 0 & 0 & 0 & 0 & 3 & 0 & 1 & 0 & 0 & 1 & 0 & 1 & 0 & 1 & 0 & 0 & \\
\hline 21. Cape Verde & 28 & 2 & 1 & 0 & 0 & 0 & 1 & 0 & 0 & 0 & 0 & 0 & 0 & 0 & 0 & 0 & 0 & 0 & 0 & 0 & 0 & 0 & 0 & 0 & 0 & 0 & 0 & 0 & 0 & 0 & 0 & 0 & 19 & 4 & 1 & \\
\hline TOTAL & 792 & 268 & 9 & 0 & 0 & 0 & 248 & 3 & 0 & 0 & 1 & $\begin{array}{ll}0 & 1\end{array}$ & 10 & 0 & 37 & 0 & 1 & 132 & 0 & 0 & 0 & $0 \quad 0$ & 0 & 25 & 2 & 14 & 27 & 0 & 2 & 4 & 2 & 1 & 20 & 4 & 1 & \\
\hline
\end{tabular}




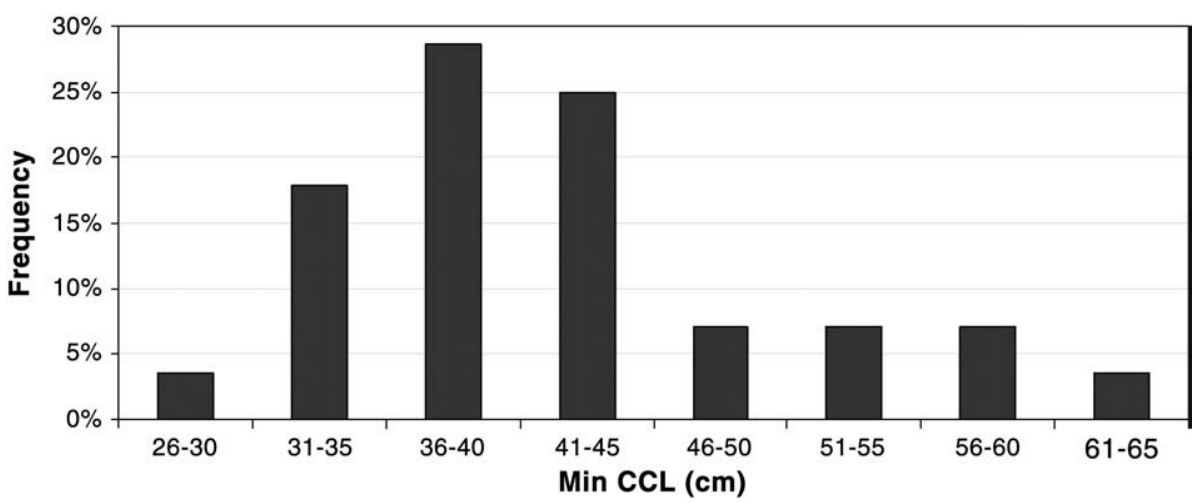

Fig. 2. Minimum curve carapace length (min CCL) distribution from the hawksbill sea turtles used in our study.

haplotype network to obtain further insights into the haplotype relationships. We constructed a median-joining network linking the 28 haplotypes using Network program (http://www.fluxus-technology. com/). To simplify, we discarded the divergent Mx1a, with a 10-bp insertion, and haplotypes R, S, T and U that have been observed only in $\mathrm{E}$. imbricata $\times$ C. caretta hybrids (Bowen et al., 2007b). Default parameters were used for obtaining the median joining network tree. Haplotype frequencies, Nei's (1987) haplotype diversity (h) and nucleotide diversity $(\pi)$ values of mtDNA sequences were calculated using Arlequin v.3.11 (Excoffier et al., 2005). Genetic differentiation between the Cape Verde foraging ground and nesting populations, and western foraging grounds, was quantified using the exact test of population differentiation (Raymond and Rousset, 1995) and Phi statistics $\left(\varphi_{\mathrm{ST}}\right)$ (Excoffier

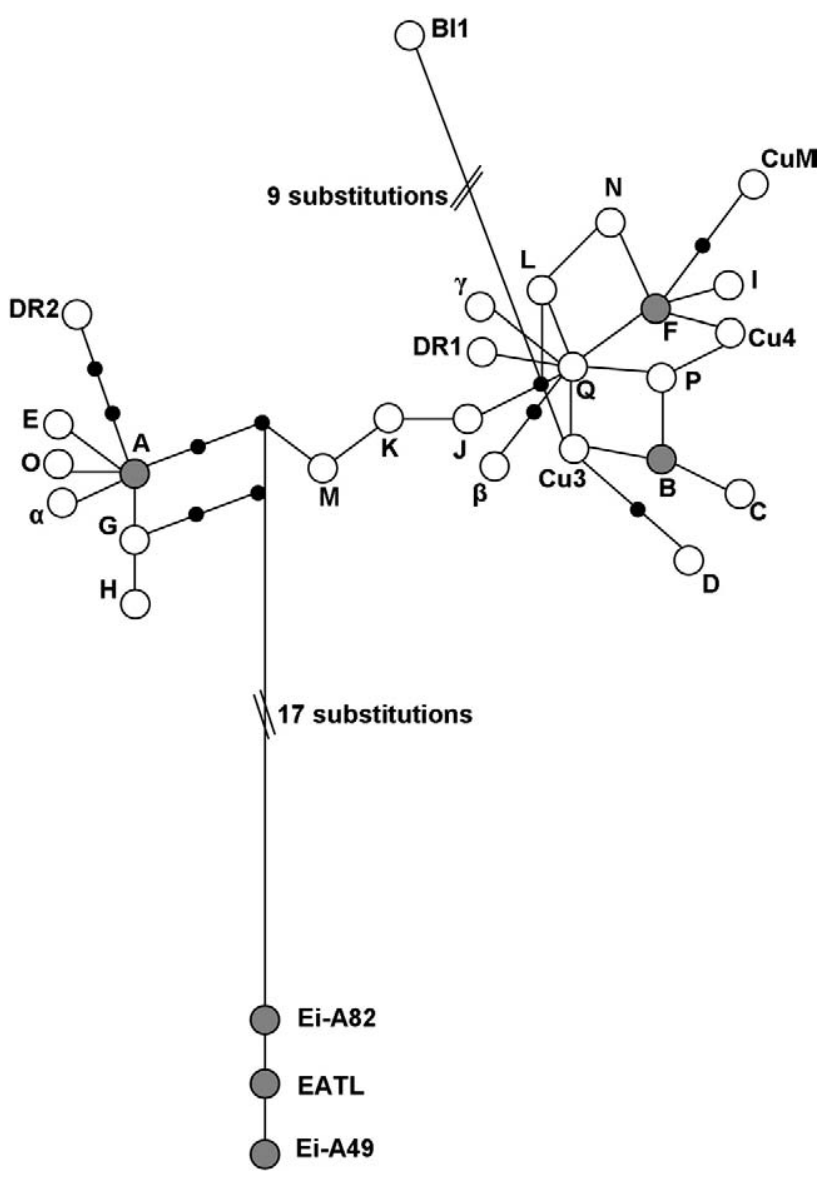

Fig. 3. Median-joining haplotype network of hawksbill haplotypes. Haplotype colours denote locations (Grey: Cape Verde; White: Other Locations). The median vectors that represent hypothetical intermediates or unsampled haplotypes are shown in black circles. Haplotypes R, S, T, U as well as Mx1a are not represented (see text for details). et al., 1992), using 10,000 permutations. All computations were carried out by the program Arlequin v.3.11 (Excoffier et al., 2005).

\section{Results and discussion}

Minimum curve carapace length (min CCL) varied from 27 to $62.8 \mathrm{~cm} \quad($ mean $=42.25 \mathrm{~cm}$; Fig. 2). We detected six haplotypes, including two previously unidentified: Ei-A49 and Ei-A82 (GenBank accession nos. GU138122 and GU138123; 14\% and 4\% of the total samples respectively). Haplotype Ei-A49 differed from haplotype EATL by a single transition at position 69, and Ei-A82 differed by a single transition from the same haplotype at position 305 . The EATL haplotype was found in the vast majority of the sampled juveniles (68\% of the total samples). This haplotype has been previously detected in a sample of four turtles from a market in São Tome (western Africa) and in one juvenile from the U.S. Virgin Islands feeding area $(0.16 \%$ of the juvenile Caribbean stocks) (Bowen et al., 2007b). The remaining sequences observed shared previously described haplotypes found in Caribbean and western Atlantic nesting populations - Ei A (7\%), Ei B (4\%), and Ei F (4\%) (Table 1). FindModel showed that the model of nucleotide substitution that best fits the data was Tamura-Nei (Tamura and Nei, 1993).

The median-joining network revealed that the vast majority of the Caribbean haplotypes were grouped in a major cluster, whereas the haplotype EATL and the two newly obtained haplotypes from Cape Verde constituted a highly divergent cluster (Fig. 3).

The haplotype (h) and nucleotide ( $\pi$ ) diversities of mtDNA sequences were 0.529 (sd 0.105 ) and 0.017 (sd 0.009) respectively (Table 2). Cape Verde foraging ground showed the second lowest $\mathrm{h}$ value from all the Atlantic ones (Table 2). The lowest value was obtained for Texas, which is mainly composed by stranded juveniles from only one rookery at Yucatan, Mexico (93\% of the individuals are from this rookery). However, the sample from Cape Verde presented the highest level of $\pi$ value (Table 2), indicating the presence of individuals from highly divergent clades.

Table 2

Sample sizes (N), number of haplotypes, haplotype (h) and nucleotide ( $\pi$ ) diversities of Cape Verde and all studied foraging areas in the Atlantic. Standard deviation values are shown (sd). References: (Bowen et al., 1996, 2007b; Díaz-Fernández et al., 1999).

\begin{tabular}{lrrll}
\hline Foraging locations & \multicolumn{1}{c}{$\mathrm{N}$} & Haplotypes & $\mathrm{h}(\mathrm{sd})$ & $\pi(\mathrm{sd})$ \\
\hline Texas & 42 & 3 & $0.180(0.077)$ & $0.000(0.001)$ \\
Bahamas & 78 & 9 & $0.740(0.024)$ & $0.009(0.005)$ \\
Cuba A & 43 & 7 & $0.559(0.083)$ & $0.008(0.005)$ \\
Cuba B & 111 & 9 & $0.720(0.027)$ & $0.010(0.006)$ \\
Cuba D & 56 & 11 & $0.821(0.031)$ & $0.010(0.006)$ \\
Dominican Republic & 90 & 9 & $0.669(0.034)$ & $0.010(0.005)$ \\
Puerto Rico & 138 & 9 & $0.705(0.027)$ & $0.009(0.005)$ \\
Buck Island, USVI & 68 & 10 & $0.757(0.035)$ & $0.012(0.006)$ \\
Cape Verde & 28 & 6 & $0.529(0.105)$ & $0.017(0.009)$ \\
& & & &
\end{tabular}


As expected, the Cape Verde foraging ground showed a high degree of genetic differentiation with respect to all known nesing popultions $\left(\varphi_{\mathrm{ST}} \mathrm{N} 0.745\right.$, pb0.001; exact pb0.001). In fact, the vast majority of the individuals sampled carried an orphan and very divergent haplotype (Table 1; Fig. 3). Furthermore, the comparison of Cape Verde Islands with other FGs revealed, in all cases, statistically significant differences $\left(\varphi_{\mathrm{ST}} \mathrm{N} 0.752\right.$, p b 0.001; exact pb0.001). These results are in accordance with those found in previous studies of hawksbill foraging grounds, where it has been shown that these areas are not homogenous across regions and their composition is correlated with nesting population sizes, oceanic currents, and a relative preference for feeding close to natal areas (Bowen et al., 2007b; Bowen and Karl, 2007; Blumenthal et al., 2009).

Our dataset did not allow us to conduct a mixed stock analysis (MSA), since more than $86 \%$ of the individuals carried unique haplotypes whose origin (i.e. nesting population) have not been identified to date. The accuracy of the MSA is known to be limited by factors including incomplete sampling of potential sources, insufficient resolution of the markers used to infer the genetic structure, and insufficient levels of differentiation (Chapman, 1996; Pella and Masuda, 2001; Bolker et al., 2003; Pella and Masuda, 2005; Bolker et al., 2007). The finding of the haplotypes A, B and F, identified in various Caribbean and western Atlantic NPs, albeit at low frequencies, may indicate occasional transatlantic movements during developmental stages of the species as has been previously suggested (Marcovaldi and Filippini, 1991; Bellini et al., 2000; Bowen et al., 2007b; Grossman et al., 2007). Hence, this hawksbill foraging ground appears to be composed primarily of turtles from regional nesting colonies (i.e. eastern Atlantic), with some individuals derived from rookeries in the opposite margin of the ocean basin. However, we cannot discard the possibility that all the Cape Verde juveniles belong to a single nearby rookery as in the case of Texas' aggregation.

Indeed, there are several conservation and research implications from the present study. As noted above, the conservation of Cape Verde is a priority for the species. In 2008, the Cape Verde government developed a conservation and management plan to protect sea turtles in that area (PNCTMCV; Araújo, 2008). Our results suggest that solution to the conservation threats needs the collaboration with other countries linked to Cape Verde through migration and dispersal, as occurs with other species of sea turtle in this archipelago (Monzón-Argüello et al., 2009). The genetic distinctiveness of this foraging aggregation highlights the necessity of its conservation since human threats are affecting an unknown number of nesting population whose size and resilience are still not known and that may already be in danger. There is a need for increased understanding of the links between the occurrence of juvenile turtle on foraging grounds and potential source rookeries (Hays, 2008). Our inability to ascertain the origin of putative eastern Atlantic stocks in our samples highlights the fact that the incomplete haplotype baseline of contributing nesting populations in the eastern Atlantic currently hampers progress of genetic studies and, consequently, a priority for evaluation on the conservation and management issues related to foraging aggregations in this region. To enhance conservation, we recommend additional research, particularly expanding the genetic analysis throughout the west coast of Africa to include unsampled areas of a migratory and critically endangered sea turtle species. A further research direction that also promises to be fruitful would be the inclusion of oceanographic particle tracking models in attempting to predict drift scenarios and potential source populations for juveniles encountered in remote locations (Hays and Marsh, 1997).

\section{Acknowledgements}

We thank G. Évora, E. Abella, P. Sanz, the monitors and volunteers of Cabo Verde Natura 2000, students of ISECMAR and all the people that contribute to sampling and field collection. We also thank $\mathrm{N}$. Varo, J. Muñoz and A. Abreu-Grobois for helpful comments on earlier versions on this manuscript. We are grateful to the Cabo Verde Ministry of the Environment (General Direction for the Environment), INDP (National Fisheries Institution), the Canary Islands government, Instituto Canario de Ciencias Marinas, Estación Biológica de Doñana, and Fundación BBVA for helping with the field and laboratory equipment. We would like to thank G. C. Hays and two anonymous reviewers for constructive criticism that lead to an improvement of this manuscript. CMA was supported by a PhD grant from the Canary Islands government.

\section{References}

Abreu, A., Le Roux, R. 2008. Hawksbill Genetics Explained. In: Mast, R.B., Bailey, L.M., Hutchinson, B.J. (Eds.), SWOT Report-The State of the World's Sea Turtles, vol. 3.

Abreu-Grobois, F.A., Horrocks, J., Formia, A., LeRoux, R., Velez-Zuazo, X., Dutton, P., Soares, L., Meylan, P., Browne, D., 2006. New mtDNA Dloop primers which work for a variety of marine turtle species may increase the resolution capacity of mixed stock analysis. In: Frick, M., Panagopoulou, A., Rees, A.F., Williams, K. (Eds.), 26th Annual Symposium on Sea Turtle Biology and Conservation, Crete, Greece. 179 pp.

Araújo, S., 2008. Plano nacional para a conservaçao das tartarugas marinhas em Cabo Verde. Ministério do Ambiente. Desenvolvimento Rural e Recursos Marinhos, Internal Report.

Bass, A.L., Good, D.A., Bjorndal, K.A., Richardson, J.I., Hillis, Z.M., Horrocks, J.A., Bowen, B.W., 1996. Testing models of female reproductive migratory behaviour and population structure in the Caribbean hawksbill turtle, Eretmochelys imbricata, with mtDNA sequences. Molecular Ecology 5, 321-328.

Beggs, J., Horrocks, J.A., Krueger, B., 2007. Increase in hawksbill sea turtle Eretmochelys imbricata nesting in Barbados, West Indies. Endangered Species Research 3, 159-168.

Bellini, C., Sanches, T.M., Formia, A., 2000. Hawksbill tagged in Brazil captured in Gabon, Africa. Marine Turtle Newsletter 87, 11-12.

Blumenthal, J.M., Abreu-Grobois, F.A., Austin, T.J., Broderick, A.C., Bruford, M.W., Coyne, M.S., Ebanks-Petrie, G., Formia, A., Meylan, P.A., Meylan, A.B., Godley, B.J., 2009 Turtle groups or turtle soup: dispersal patterns of hawksbill turtles in the Caribbean. Molecular Ecology 18, 4841-4853.

Bolker, B., Okuyama, T., Bjorndal, K., Bolten, A., 2003. Sea turtle stock estimation using genetic markers: accounting for sampling error of rare genotypes. Ecological Applications 13, $763-775$.

Bolker, B.M., Okuyama, T., Bjorndal, K.A., Bolten, A.B., 2007. Incorporating multiple mixed stocks in mixed stock analysis: 'many-to-many' analyses. Molecular Ecology 16, 685-695.

Bolten, A.B., 1999. Techniques for measuring sea turtles. Research and Management Techniques for the Conservation of Sea TurtlesIn: Eckert, K.L., Bjorndal, K.A., AbreuGrobois, F.A., Donnelly, M. (Eds.), IUCN/SSC Marine Turtle Specialist Group Publication No. 4.

Bolten, A.B., 2003. Variation in sea turtle life history patterns: neritic vs. oceanic develpmental stages. CRC Marine Biology Series. In: Lutz, P.L., Musick, J.A., Wyneken, J. (Eds.), The Biology of Sea Turtles, volume II. CRC Press Inc., Boca Raton, FL, pp. 243-257.

Bowen, B.W., Karl, S.A., 2007. Population genetics and phylogeography of sea turtles. Molecular Ecology 16, 4886-4907.

Bowen, B.W., Bass, A.L., GarciaRodriguez, A., Diez, C.E., vanDam, R., Bolten, A., Bjorndal, K.A., Miyamoto, M.M., Ferl, R.J., 1996. Origin of hawksbill turtles in a Caribbean feeding area as indicated by genetic markers. Ecological Applications 6, 566-572.

Bowen, B.W., Grant, S., Hillis-Starr, Z., Shaver, D.J., Bjorndal, K.A., Bolten, A.B., 2007a. The advocate and the scientist: debating the commercial exploitation of endangered hawksbill turtles. Molecular Ecology 16, 3514-3515.

Bowen, B.W., Grant, W.S., Hillis-Starr, Z., Shaver, D.J., Bjorndal, A., Bolten, A.B., Bass, A.L., 2007b. Mixed-stock analysis reveals the migrations of juvenile hawksbill turtles (Eretmochelys imbricata) in the Caribbean Sea. Molecular Ecology 16, 49-60.

Broderick, D., Moritz, C., Miller, J.D., Guinea, M., Prince, R.J., Limpus, C.J., 1994. Genetic studies of the hawksbill turtle: evidence for multiple stocks and mixed feeding grounds in Australian waters Pacific. Conservation Biology 1, 123-131.

Browne, D.C., Horrocks, J.A., Abreu-Grobois, F.A., in press. Population subdivision in hawksbill turtles nesting on Barbados, West Indies, determined from mitochondrial DNA control region sequences. Conservation Genetics. doi:10.1007/s10592-009-9883-3.

Canin, J., 1989. International Trade in Sea Turtle Products. In: Eckert, S.A., Eckert, K.L. Richardson, T.H. (Eds.), Proc. Ninth Annual Workshop on Sea Turtle Conservation and Biology. NOAA Tech. Memo. NMFS-SEFC-232, pp. 27-29.

Chapman, R.W., 1996. A mixed stock analysis of the green turtle: the need for null hypotheses. In: Bowen, B.W., Witzell, W.N. (Eds.), Proceedings of the Internatonal Symposium on Sea Turtle Conservation Genetics. NOAA Technical Memorandum NMFS-SEFSC-396, pp. 137-146.

Díaz-Fernández, R., Okayama, T., Uchiyama, T., Carrillo, E., Espinosa, G., Marquez, R., Diez, C., Koike, H., 1999. Genetic sourcing for the hawksbill turtle, Eretmochelys imbricata, in the northern Caribbean region. Chelonian Conservation and Biology 3, 298-300.

Excoffier, L., Smouse, P.E., Quattro, J.M., 1992. Analysis of molecular variance inferred from metric distances among DNA haplotypes: application to human mitochondrial DNA restriction data. Genetics 131, 479-491.

Excoffier, L., Laval, G., Schneider, S., 2005. Arlequin (version 3.0): an integrated software package for population genetics data analysis. Evolutionary Bioinformatics Online $1,47-50$.

Fretey, J., 2001. Biogeography and Conservation of Marine Turtles of the Atlantic Coast of Africa / Biogéographie et conservation des tortues marines de la cóte atlantique de l'Afrique. UNEP/CMS Secretariat, Bonn, Germany. 
Groombridge, B., Luxmoore, R., 1989. The Green Turtle and Hawksbill (Reptilia: Cheloniidae): World Status, Exploitation and Trade. Secretariat of CITES, Lausanne, Switzerland.

Grossman, A., Bellini, C., Fallabrino, A., Formia, A., Mba Mba, J., Nzi Mba, J., Obama, C., 2007. Second TAMAR-tagged hawksbill recaptured in Corisco Bay, West Africa. Marine Turtle Newsletter 116, 26

Hays, G.C., 2008. Sea turtles: a review of some key recent discoveries and remaining questions. Journal of Experimental Marine Biology and Ecology 356, 1-7.

Hays, G.C., Marsh, R., 1997. Estimating the age of juvenile loggerhead sea turtles in the North Atlantic. Canadian Journal of Zoology-Revue Canadienne De Zoologie 75, 40-46.

León, Y.M., Bjorndal, K.A., 2002. Selective feeding in the hawksbill turtle, an important predator in coral reef ecosystems. Marine Ecology Progress Series 245, 249-258.

Marcovaldi, M.A., Filippini, A., 1991. Trans-Atlantic movement by a juvenile hawksbill turtle. Marine Turtle Newsletter 52, 3.

Márquez, M.R., 1990. FAO species catalogue: sea turtles of the world. An annotated and illustrated catalogue of sea turtles species known to date. FAO Fisheries Synopsis 125, vol. 11. FAO, Rome.

Meylan, A.B., 1988. Spongivory in hawksbill turtles: a diet of glass. Science 239, 393-395.

Meylan, A.B., 1999. Status of the hawksbill turtle (Eretmochelys imbricata) in the Caribbean region. Chelonian Conservation and Biology 3, 177-184.

Monzón-Argüello, C., Rico, C., Carreras, C., Calabuig, P., Marco, A., López-Jurado, L.F., 2009. Variation in spatial distribution of juvenile loggerhead turtles in the Eastern Atlantic and Western Mediterranean sea. Journal of Experimental Marine Biology and Ecology 373, 79-86.

Mortimer, J.A., Donnelly, M., 2008. Eretmochelys imbricata. IUCN 2009. IUCN Red List of Threatened Species. Version 2009.2. bwww.ucnredlist.orgN. Downloaded on 11 December 2009.
Nei, M., 1987. Molecular Evolutionary Genetics. Columbia University Press, New York. Parsons, J.J., 1972. The hawksbill turtle and the tortoise shell trade. Études de géographie tropicale offertes a Pierre Gourou, Mouton, Paris, pp. 45-60.

Pella, J., Masuda, M., 2001. Bayesian methods for analysis of stock mixtures from genetic characters. Fishery Bulletin 99, 151-167.

Pella, J., Masuda, M., 2005. Classical discriminant analysis, classification of individuals, and source population composition of mixtures. In: Cadrin, S.X., Friedland, K.D., Waldman, J.R. (Eds.), Stock identification methods: applications in fishery science. Elsevier, Inc., San Diego, CA, pp. 517-552.

Raymond, M., Rousset, F., 1995. An exact test for population differentiation. Evolution 49, 1280-1283.

Schofield, G., Bishop, C.M., MacLean, G., Brown, P., Baker, M., Katselidis, K.A., Dimopoulos, P., Pantis, J.D., Hays, G.C., 2007. Novel GPS tracking of sea turtles as a tool for conservation management. Journal of Experimental Marine Biology and Ecology 347, 58-68.

Tamura, K., Nei, M., 1993. Estimation of the number of substitutions in the control region of mitochondrial DNA in humans and chimpanzees. Molecular Biology and Evolution 10, 512-526.

Troëng, S., Dutton, P.H., Evans, D., 2005. Migration of hawksbill turtles Eretmochelys imbricata from Tortuguero, Costa Rica. Ecography 28, 394-402.

Velez-Zuazo, X., Ramos, W.D., van Dam, R.P., Diez, C.E., Abreu-Grobois, A., McMillan, W.O., 2008. Dispersal, recruitment and migratory behaviour in a hawksbill sea turtle aggregation. Molecular Ecology 17, 839-853. 